\title{
latrogenic post-pulpectomy cervicofacial subcutaneous emphysema in a paediatric patient
}

\author{
Vir Singh, ${ }^{1,2}$ Latha Ganti (10 , ${ }^{1,3}$ Joshua D Haupt, ${ }^{4}$ Bruce Marshall ${ }^{4}$
}

${ }^{1}$ University of Central Florida College of Medicine, Orlando, Florida, USA

${ }^{2}$ Ocala Regional Medical Center, Ocala, Florida, USA ${ }^{3}$ Envision Physician Services, Plantation, Florida, USA ${ }^{4}$ Memorial Health University Medical Center, Savannah, Georgia, USA

\section{Correspondence to} Professor Latha Ganti; lathagantimd@gmail.com

Accepted 18 February 2020

D) Check for updates

(C) BMJ Publishing Group Limited 2020. No commercial re-use. See rights and permissions. Published by BMJ.

\begin{tabular}{l}
\hline To cite: Singh V, Ganti L, \\
Haupt JD, et al. BMJ Case \\
Rep 2020;13:e234074. \\
doi:10.1136/bcr-2019- \\
234074 \\
\hline
\end{tabular}

\section{DESCRIPTION}

A 9-year-old boy with no medical history presented to the emergency department (ED) directly from the dental clinic with a main problem of left-sided facial swelling following a dental procedure. An hour prior, he underwent a pulpotomy procedure for tooth $\mathrm{J}$. He received local infiltration of lidocaine with epinephrine between teeth I and J and nitrous oxide via face mask. A dental handpiece was used to section the tooth and a stainless-steel crown was placed. During this procedure, the patient was noted to have progressive left-sided facial swelling to the point of being unable to open the left eye. $\mathrm{He}$ was given diphenhydramine and sent to the ED. He was found to have swelling and crepitus in the periorbital and maxillary regions. This was concerning for subcutaneous emphysema, and confirmed on facial imaging (figure 1). At re-examination 1 hour later (figure 2), there was spontaneous partial resolution of symptomatology. At 1-week follow-up, he had near-complete resolution of facial swelling with no further complications.

Iatrogenic subcutaneous emphysema in dental procedures is a rare but well-documented phenomenon. It occurs when interruption of intraoral epithelium combined with positive pressure forms a tract that can reach the periorbital area and travel down to the mediastinum. Air-driven handpieces have been implicated in the majority of such documented cases, with positive pressure ventilation also contributing. Most cases resolve within 7-10 days with no complications. In a literature review

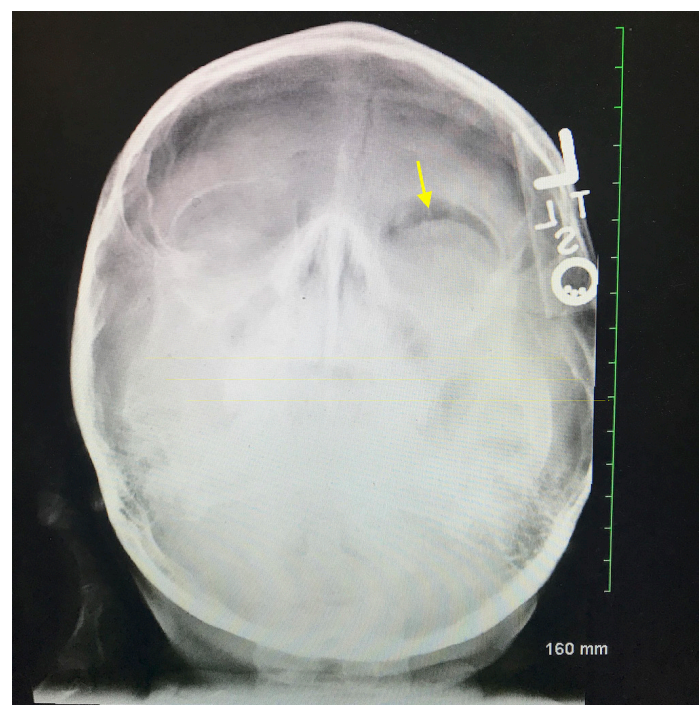

Figure 1 Patient photographed at re-examination with partial resolution of facial swelling.

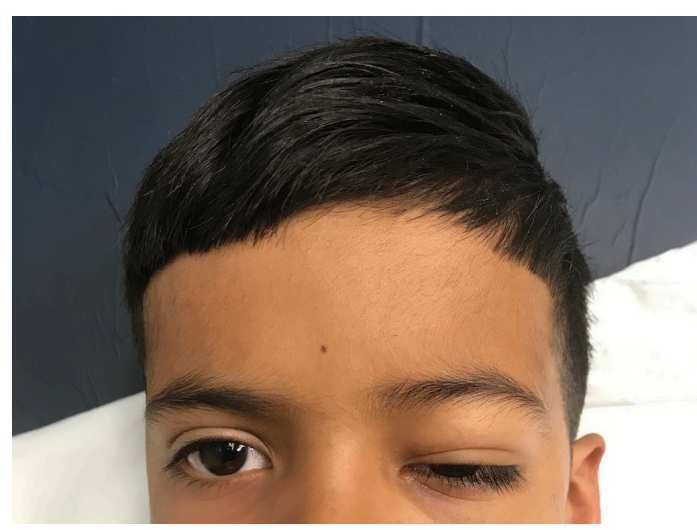

Figure 2 Water's view facial radiograph demonstrating subcutaneous emphysema in the left retro-orbital area.

\section{Patient's perspective}

I (patient's mother) was concerned my child was having an allergic reaction, and that he might stop breathing. The swelling scared me. I was very relieved and grateful for the care from the emergency room doctors!

\section{Learning points}

- Subcutaneous emphysema is a rare but welldocumented phenomenon that may occur secondary to routine dental procedures, most cases self-resolve within 7-10 days

- There is no evidence in favour of routine antibiotics for infection prophylaxis or steroids for inflammation

of 32 cases, 5 resulted in significant complications- 3 of which were associated with intubation or extubation. The two cases of complications in non-intubated patients were a focal alveolitis in a patient undergoing an extraction, and air emboli, seizures, and memory deficit in a patient undergoing an extraction. There is no consensus on treatment. Some treat with prophylactic antibiotics and/or steroids, while with others they adopt only watchful waiting. ${ }^{1}$

Acknowledgements This research was supported (in whole or in part) by HCA Healthcare and/or an HCA Healthcare affiliated entity. The views expressed in this publication represent those of the author(s) and do not necessarily represent the official views of HCA Healthcare or any of its affiliated entities. 
Contributors VS, JDH and BM were physicians for the patient in the emergency department. VS and LG completed the case report, which LG then edited and provided further recommendations before submission.

Funding The authors have not declared a specific grant for this research from any funding agency in the public, commercial or not-for-profit sectors.

Competing interests None declared.

Patient consent for publication Parental/guardian consent obtained.
Provenance and peer review Not commissioned; externally peer reviewed.

\section{ORCID iD}

Latha Ganti http://orcid.org/0000-0001-7717-3864

\section{REFERENCE}

1 McKenzie WS, Rosenberg M. latrogenic subcutaneous emphysema of dental and surgical origin: a literature review. J Oral Maxillofac Surg 2009;67:1265-8.

Copyright 2020 BMJ Publishing Group. All rights reserved. For permission to reuse any of this content visit

https://www.bmj.com/company/products-services/rights-and-licensing/permissions/

BMJ Case Report Fellows may re-use this article for personal use and teaching without any further permission.

Become a Fellow of BMJ Case Reports today and you can:

- Submit as many cases as you like

- Enjoy fast sympathetic peer review and rapid publication of accepted articles

- Access all the published articles

Re-use any of the published material for personal use and teaching without further permission

Customer Service

If you have any further queries about your subscription, please contact our customer services team on +44 (0) 2071111105 or via email at support@bmj.com.

Visit casereports.bmj.com for more articles like this and to become a Fellow 